\title{
PERILAKU INTERAKSI SOSIAL MONYET HITAM DARE (MacacamauraSchinz, 1825) DI TAMAN WISATA ALAM LEJJA KABUPATEN SOPPENG
}

\author{
(Social Interaction Behavior of Dare Black Monkey (Macaca mauraSchinz, 1825) in the \\ Lejja Natural Tourism Park Soppeng District)
}

\author{
Dewi Anggita Munir ${ }^{1}$, Hadijah Azis K. ${ }^{2}$, dan Andi Rosdayanti ${ }^{3}$ \\ ${ }^{1}$ Program Studi Kehutanan Fakultas Kehutanan,Universitas Andi Djemma Palopo \\ ${ }^{2,3}$ Dosen Universitas Andi Djemma Palopo \\ Dewianggitamunir@gmail.com
}

\begin{abstract}
Sulawesi island is a unique island among other islands in indonesia. This research aims to find out the social interaction behaviour of Dare Black Monkey (Macaca maura) in the Lejja natural tourism park. This animal is an endemic in Sulawesi island, located in South Sulawesi Province and categorixed as an endangered species by the IUCN, therefore its existence must be protected. The method was used field observation and focal animal sampling. The object was detremined in 15 Macaca maura based on age and sexuality in a group.Social interaction behaviour was recorded, namely the behavior of playing, grooming, coitus, conflict. Based on the results that the high social behaviour frequency of playing activity was owned by the young male (72 times) and the children (56 times), as well as grooming by young male and children have the highest frequency (31 times). Frequency of coitus and agonistic behaviours was owned by adult male with 14 times and 5 times respectively.However, the longest time proportion of playing was used by children with 10.602 second $(62,01 \%)$, while the total and time percentage of coitus have the lowest value (240 second or 2,11\% and 300 second or 2,58\% perspectively) by adult ages.
\end{abstract}

Kata Kunci :, Macaca maura, social behavior, grooming, Lejja natural tourism park

\begin{abstract}
ABSTRAK
Pulau sulawesi merupakan pulau unik diantara pulau-pulau lainnya di Indonesia. Penelitian ini bertujuan untuk mengetahui perilaku interaksi sosial Monyet Hitam Dare (Macaca maura) di Taman Wisata Alam Lejja. Hewan ini merupakan hewan endemik pulau Sulawesi tepatnya berada di Provinsi Sulawesi Selatan dan dikategorikan menjadi hewan terancam punah (Endengared species) oleh IUCN sehingga keberadaanya harus dilindungi. Metode yang digunakan yaitu observasi lapangan kemudian menentukan objek penelitian yaitu 15 ekor Macaca maura berdasarkan umur dan jenis kelamin dalam satu kelompok. Kemudian mencatat perilakunya menggunakan metode focal animal sampling yaitu mencatat perilaku satu individu dalam waktu tertentu. Perilaku sosial yang diamati yaitu perilaku bermain, menelisik, kawin, konflik. Berdasarkan hasil penelitian bahwa ferekuensi perilaku sosial bermain tertinggi dimiliki oleh kelompok umur jantan remaja (72 kali) dan anak-anak (56 kali), demikian halnya dengan perilaku sosial menelisik tertinggi dimilki oleh kelompok umur jantan remajadan anak-anak (31 kali). Frekuensi perilaku sosial kawin dan konflik tertinggi dimiliki oleh kelompok umur jantan dewasa dengan nilai masing-asing frekuensi 14 kali dan 5 kali. Sedangkan durasi waktu yang digunakan paling lama adalah perilaku bermain oleh kelas umur anak-anak dengan porsi waktu 10.602 detik (62,01\%), sementara total dan presentasi waktu perilaku kawin bagi kelompok umur dewasa adalah terendah yaitu 240 detik $(2,11 \%)$ dan 300 detik $(2,58)$.
\end{abstract}

Kata Kunci : Macaca Maura, perilaku social, menelisik, TWA Lejja 


\section{PENDAHULUAN}

Macaca Maura merupakan satwa mamalia endemik Pulau Sulawesi yang termasuk dalam Ordo Primata. Satwa ini adalah kera atau monyet berekor sangat pendekyang dikenal dengan nama lokal monyet hitam dare. Hidup secara berkelompok dengan jumlah individu 12 ekor - 46 ekor setiap kelompok yang dipimpin oleh seekor jantan dewasa (Labahi, 2015).Dari tujuh spesies Macaca endemik sulawesi (Witten et. al, 1987), Macaca maura tersebar khusus di Propinsi Sulawesi Selatan dan Sulawesi Barat.

Taman Wisata Alam Lejja merupakan wilayah peneyebaran Macaca maura yang terletak di Kabupaten Soppeng Sulawesi Selatan. kawasan konservasi ini adalah habitat alami bagi satwa liar genus Macaca endemik hususnya jenis Macaca maura.Berdasarkan Surat Keputusan Menteri Kehutanandan Perkebunan (SK.Menhutbun) No. 169/KptsII/2000 tanggal 29 Juni 2000 dengan luas wilayah TWA Lejja $\pm 1.318 \mathrm{Ha}$. Adanya keberadaan satwa ini membuat salah satu daya tarik wisata karena perilakunya yang unik, namun kondisi TWA Lejja saat ini telah mengalami penyusutan akibat kerusakan dan perubahan fungsi kawasan hutan, sehingga berdampak pada populasi Macaca maura diperkirakan mengalami penurunan secara signifikan.

Berdasarkan status konservasi, Macaca maura telah dimasukan dalam Appendix II CITES yang berarti bahwa populasi spesies ini akan terancam apabila perdagangannya tidak diatur. Sedangkan menurut kategori IUCN, status Macaca maura adalah terancam punah (Endengared species).Pemerintah menetapkan jenis ini dilindungi berdasarkan Peraturan Menteri Lingkungan Hidup dan Kehutanan Republik Indonesia No. 20/MENLHK/SETJEN/KUM.1/6/2018J tentang Penetapan Jenis Tumbuhan dan Satwa yang Dilindungi.
Terdapat 10 kelompok Macaca mauradalam TWA tersebut, dimana tidak terlepas dari interaksi sosial baik dalam kelompoknya maupun kempok lain. Interaksi sosial yang dilakukan Macaca maura memunculkan berbagai aktifitas antara individu dalam suatu populasi. Aktivitas yang dimaksud antara lain yaitu bermain (playing), kawin (coitus), menelisik (grooming), dan konflik (agonistic). Perilaku sosial Macaca maurayang terbiasa hidup berkelompok dengan aktivitas-aktivitas yang spesifik mempengaruhi luas wilayah jelajah dan mencari makan.

Kerusakan hutan disebabkan adanya perambahan hutan menjadi perkebunan dan pemukiman. Selain itu, maraknya perburuan liar terhadap anak Macaca Maura untuk diperjualbelikan dan dipelihara menyebabkan populasi dan habitat Macaca Maura semakin menurun.Oleh sebab itu, peneliti tertarik untuk melakukan penelitian terhadap objek tersebut khususnya berkaitan dengan perilaku sosialnya. Hasil yang akan diperoleh dari penelitian ini dapat menjadi acuan dasar untuk upaya konservasi terhadap primata, sehingga keberadaannya di alam dapat dipertahankan. Adapun salah satu upaya yang dapat dilakukan yaitu melalui kegiatan perlindungan dan pelestarian terhadap populasidan habitat Macacamaura.

Tujuan dari penelitian ini yaitu untuk mengetahui perilaku interaksi sosial Macaca maura di TWA Lejja. Penelitian ini diharapkan dapat digunakan sebagai data dan informasi mengenai perilaku sosial Macaca maura dan dapat dijadikan sebagai bahan perbandingan perilaku sosial Macaca maura yang berada di kawasan konservasi lainnya.

\section{METODE PENELITIAN}

Penelitian ini dilaksanakan pada bulan November 2017 sampai Januari 2018. Pengamatan dilakukan selama sembilan jam setiap hari pada dua waktu yaitu dimulai pada 
pukul 06:00-11:00 WIB dan pukul 13:0017:00 WIB. Penelitian didahului dengan observasi yang bertujuan untuk mengetahui keberadaan dan sebaran kelompokMacaca maura. Pengamatan hanya dilakukan pada satu kelompok Macaca maura berdasarkan kelas umur dan jenis kelaminya yang terdiri dari 3 individu jantan dewasa, 3 individu betina dewasa, 3 individu jantan remaja, 3 individu betina remaja dan 3 individu anak.

Pengamatan terhadap kelas umur dan jenis kelamin dilakukan dengan melihat ciriciri morfologi sebagai berikut (Groves, 1980; Supriatna dan Wahyono, 2000; Watanabe dn Brotoisworo, 1982); (i) jantan dewasa, memiliki bobot badan lebih besar yaitu sekitar 9 atau $10 \mathrm{~kg}$, memiliki bantalan duduk yang rata, dada lebih lebar pada bagian atas dan mengecil pada bagian pinggang, agresif dan kuat serta lebih tegap. (ii) betina dewasa memiliki ukuran tubuh $4-6 \mathrm{~kg}$, terdapat bantalan duduk pada tunggirnya yang berbentuk ginjal, bantalan ini akan membengkak besar dan berwararna pink bia sedang birahi,kelenjar mammae besar pada dada, tingkah laku lebih tenang. (iii) Remaja, memiliki bobot tubuh yang lebih kecil dari dewasa yakni sekitar $2,5-5 \mathrm{~kg}$, warna bulu coklat atau kehitaman tetapi tidak pekat, tidak ditumbuhi bulu atau rambut pada bagian muka, telapak tangan dan telapak kaki, khusus jantan remaja memiliki jambul pendek dan rebah serta moncong yang pendek, warna tubuh bagian ventral lebih muda daripada bagian dorsal, dan kaki biasanya lebih panjang daripada tangan. (iv) anak, mempunyai ukuran tubuh yang lebih kecil dari pradewsa, bergerak secara mandiri karena sudah lepas dari induknya atau terkadang mengikuti gerakan induknya, tidak selalu berada dalam dekapan induk, serta tingkah laku bermainnya lebih menonjol.

Metode pengamantan yang digunakan adalahsurvey denganfocal animal samplingyaitu mengamati dan mencatat perilaku satu individu dalam satu kelompok selama periode waktu tertentu(Martin dan Bateson, 1993).Pencatatan data menggunakan menggunakan instantanous sampling yaitu mencatat ada atau tidaknya aktvitas sesuai kategori perilaku dengan interval waktu yang telah ditentukan yaitu setiap 5 menit. Perilaku sosial dicatat dengan format checklist/tallysheet yang mengacu pada metode Hansen checklist berdasarkan indikator perilaku interaksi sosial yang diamati meliputi perilaku bermain (playing), kawin (coitus), menelisik (grooming), dan konflik (agonistic)(Murti, 2007).

Perhitungan persentase perilaku sosial khususnya waktu aktivitas Macaca maura perhariberdasarkan rumus Martin dan Bateson (1993) dengan rumus sebagai berikut:

Persentase waktu aktivitas perilaku s 0sial $=\frac{\begin{array}{c}\text { Waktu yang dibutuhkan } \\ \text { untuk melakukan aktuvtas }\end{array}}{\sum \mathrm{L}_{\mathrm{ama}} \text { Waktu pengamatan }} \times 100 \%$

Data aktivitas perilaku interaksi sosial harian Macaca maura pada penelitian ini dianalisa menggunakan statistik deskriptif dengan menampilkan data dalam bentuk tabel.

\section{HASIL DAN PEMBAHASAN}

\section{Karakteristik Lokasi Pengamatan}

Karakteristik lokasi pengamatan di TWA Lejja yaitu vegetasinya yang rapat dimana tingkat pertumbuhan vegetasi didominasi oleh pohon,tiang, dan pancang. Kondisi topografi pada wilayah jelajahnya yaitu berbukit dengan tekstur tanah berpasir dan berbatu. Salah satu kelompok Macaca maura yang menjadi objek penelitian adalah kelompok Macaca maura yang biasa dikenal oleh Masyarakat Mitra Polhut (MMP) dengan nama kelompok Panrenge. Kelompok ini berada pada blok pemanfaatan dengan titik koordinat $04^{\circ} 08^{\prime} 57,8^{\prime}, \mathrm{LS}$ dan $119^{\circ} 47^{\prime}$ 23,4' BT.Wilayah jelajah dari kelompok ini meliputi kawasan persawahan, kawasan hutan 
jati, kawasan hutan alam dan perkebunan masyarakat dengan luas wilayah jelajah 32,02 ha. Selain itu, wilayah jelajah dari Macaca maura ini meliputi kawasan permandian air panas, yang merupakan ciri khas dari TWA Lejja (Gambar 1.).

Jenis pohon tidur Macaca maura yang dijumpai saat penelitian yaitu pohon yang besar dan memilki banyak ranting. Pohon yang sering mereka gunakan untuk tidur adalah pohon Flamboyan (Delonix regia). Kemiri (Aleurites moluccana) dan Terap (Artocarpus odoratissimus).

\section{Perilaku Sosial Macaca maura}

Pengamatan perilaku sosial Macaca maura dilakukan dengan cara mengamati langsung dilapangan dan metode yang digunakan adalah metode transek jalur. Keberadaan Macaca maura biasanya ditandai dengan kehadiran jenis burung Kadalan sulawesi (Ramphococcyx calyorhynchus) yang mempermudah untuk menemukannya. Hal ini disebabkan adanya hubungan simbiosis komensalisme diantara mereka (Kliner, 2001). dimana burung Kadalan diuntungkan sedangkan Macaca maura tidak dirugikan maupun diuntungkan. Dalam hal ini burung Kadalan memperoleh sumber makanan seperti serangga, apabila ada sekelompok Macaca maura yang beraktivitas di suatu areal seperti pohon maupun semak, dimana dengan keberadaannya membuat serangga tersebut berterbangan dan menjadi sumber makanan bagi burung Kadalan. Adapun perilaku sosial Macaca maura yang diamati adalah sebagai berikut:

\section{Bermain (playing)}

Macaca maura mulai turun dari pohon tidurnya pada pukul 07:00 pagi hari untuk mencari makan. Bermain dilakukan di atas tanah dan di pohon dengan saling mengejar, berguling, saling mengigit, menarik-narik ekor, dan bergelantungan di pohon. Obyek permainan yang mereka gunakan pada saat pengamatan yaitu ranting pohon dan juga sisa makanan yang berada di sekitarnya. Cara bermain menggunakan ranting pohon yaitu hanya memegang dan membawanya saja, kemudian melepaskannya. Adapun dengan menggunakan sisa makanan yaitu mereka melempar-lemparkan sisa makanannya berupa sisa buah-buahan ke segala arah. Selain itu, mereka juga bermain menggunakan suara seperti pada saat memanggil kawanan atau mencari perhatian diantara mereka dengan nada suara yang yang keras tapi tidak dalam versi agresif. Bermain dilakukan terutama pada waktu kelompok berhenti di suatu lokasi setelah berjalan atau sesudah makan. Pada saat berpindah tempat juga ditemukan perilaku bermain yang didominasi oleh kelompok umur remaja dan anak.

Tingkah laku bermain dilakukan oleh semua kelompok umur dan jenis kelamin. Adapun jumlah total perilaku bermain selama 15 hari penelitian sebanyak 215 kali dengan waktu 9,8 jam.

\section{Menelisik (grooming)}

Perilaku sosial yang dilakukan Macaca maura sangat beragam, salah satunya grooming (menelisik). Groomingmerupakan salah satu perilaku sosial dalam bentuk sentuhan yang umum dilakukan dalam kelompok primata. Lee (2012) menyatakan bahwa terdapat dua jenis grooming yaitu allogrooming (perilaku dilakukan secara berpasangan yang menguntungkan kedua belah pihak) dan autogrooming (perilaku grooming yang dilakukan sendiri atau tidak berpasangan).

Aktivitas grooming yang terlihat pada saat penelitian yaitu membersihkan diri sendiri dan juga antara individu lainnya. Individu yang melakukan grooming sendiri biasanya mencari parasit atau kotoran yang menempel ditubuhnya dengan cara menggaruk-garuk badannya menggunakan tangan maupun kakinya kemudian menarik atau menyisir bulunya ketika mendapatkan kotoran atau kutu 
yang menempel. Selain itu, mereka juga menggunakan alat seperti ranting pohon yang mereka patah sendiri kemudian digunakan untuk menggaruk pada bagian tubuh yang gatal. Sedangkan Grooming yang dilakukan oleh lebih dari satu individu yaitu dengan cara berhadapan, membelakangi individu lain, kemudian mencari parasit atau kotoran satu sama lain. Terkadang parasit atau kotoran yang menempel, mereka mengkonsusmisnya kembali untuk memenuhi kebutuhan energinya.

Saat penelitiaan yang sering melakukan grooming yaitu indukan betina dan anak. Gumert (2007), menyatakan pada saat grooming, juga ditemukan perilaku kawin antara individu dewasa yang tidak berlangsung lama. Adapun jumlah total perilaku menelisik selama 15 hari penelitian sebanyak 107 kali dengan waktu 4,8 jam.

\section{Kawin (coitus)}

Kawin merupakan perilaku sosial yang bertujuan untuk reproduksi. Faktor yang menyebabkan terjadinya perkawinan antara individu yaitu faktor umur dan telah mencapai tingkat kematangan seksual. Hal ini sejalan dengan hasil pengamatan oleh Nugroho dan Sugiyarto (2015) yang menyatakan bahwa Perilaku Bereproduksi pada Macaca mencapai kedewasaan atau umur minimum dapat melakukan perkawinan berkisar antara 3,5-5 tahun dan telah mencapai Kematangan seksual. Macaca maura termasuk satwa multimale-multifemale, dimana satu jantan atau satu betina dewasa dapat kawin dengan banyak lawan jenisnya.

Perilaku kawin merupakan aktivitas yang jarang terlihat pada saat penelitian berlangsung. Pengamatan perilaku kawin hanya berlangsung pada saat mencari makan dan istirahat. Pada waktu ini ditemukan individu dewasa yang melakukan perkawinan dalam waktu yang singkat. Proses kawin yang teramati dilapangan yaitu mulai dari individu jantan dewasa mendekati individu betina dewasa dengan melakukan perilaku grooming maupun langsung melakukan proses kawin. Setelah itu, dilanjutkan dengan mengendus bagian pantat. individu betina untuk melihat apakah individu betina sudah siap untuk kawin. Kemudian jantan dewasa menaiki betina dari belakang hingga selesai. Setelah kawin, individu jantan dewasa kembali melakukan grooming dan ada juga individu jantan yang langsung meninggalkan betina tanpa melakukan kegiatan apapun. Adapun jumlah total perilaku kawin selama 15 hari penelitian sebanyak 6 kali dalam waktu 0,15 jam.

\section{Konflik (conflict)}

Pada saat penelitian, terjadi konflik pada Macaca maura di setiap aktivitasnya baik pada saat mencari makan, berpindah tempat dan aktivitas istirahat. Hal ini sejalan dengan pendapat Tasin (2009), tingkah laku konflik umum dilakukan primata untuk mempertahankan wilayah, memperebutkan makanan serta untuk mempertahankan dominansi intergroup seperti meperebutkan betina. Mondoringin (2016) menyatakan bahwa perilaku konflik yang terjadi biasanya memperebutkan betina untuk kawin.Pada saat penelitian Aktivitas yang dilakukan Macaca maura pertama kali setelah turun dari pohon tidurnya yaitu mencari makan. Pada aktivitas ini sering dijumpai konflik dalam hal perebutan makanan. Mereka saling berebut makanan apabila sumber pakan yang tersedia tidak mencukupi kelompok Macacaatau sedikit. Selain itu apabila yang menemukan makanan terlebih dahulu adalah individu anak maka akan dirampas oleh individu dewasa atau individu yang dominan dalam kelompok tersebut.

Konflik juga terjadi pada aktivitas berpindah tempat. ditemukan adanya dua kelompok Macaca yang saling bertemu,kemudian terjadi konflik atau perkelahian yang bisa memunculkan suarasuara keras. Setiap individu dominan 
mempertahankan daerah jelajahnya masingmasing dengan cara berkelahi dengan kelompok lainnya. Cara berkelahinya yaitu dengan menegakkan badan, menampakkan seluruh giginya, serta mengeluarkan suara yang nyaring dan keras. Kemudian jantan dominan memulai perkelahian dengan mencakar, mengigit, saling kejar mengejar sampai ada satu kelompok yang kalah dan pergi. Ketika konflik sedang berlangsung betina dewasa dan anak berlarian menjauh dari tempat konflik untuk menyelamatkan diri.

Adapun pada saat proses kembali kepohon tidur, yaitu untuk mencari posisi tidur masing-masing sering ditemukan individu jantan dominan berkonflik dengan individu remaja maupun anak karena masalah posisi tempat tidur. Saat penelitian, individu remaja lebih duluan menemukan tempat untuk tidur, tetapi datang individu dewasa kemudian menggoyangkan pohon atau ranting agar individu remaja pindah dari tempat tersebut. Adapun total keseluruhan konflik yang terjadi saat penelitian sebesar 58 kali dalam waktu 2,9 jam selama 15 hari pengamatan.

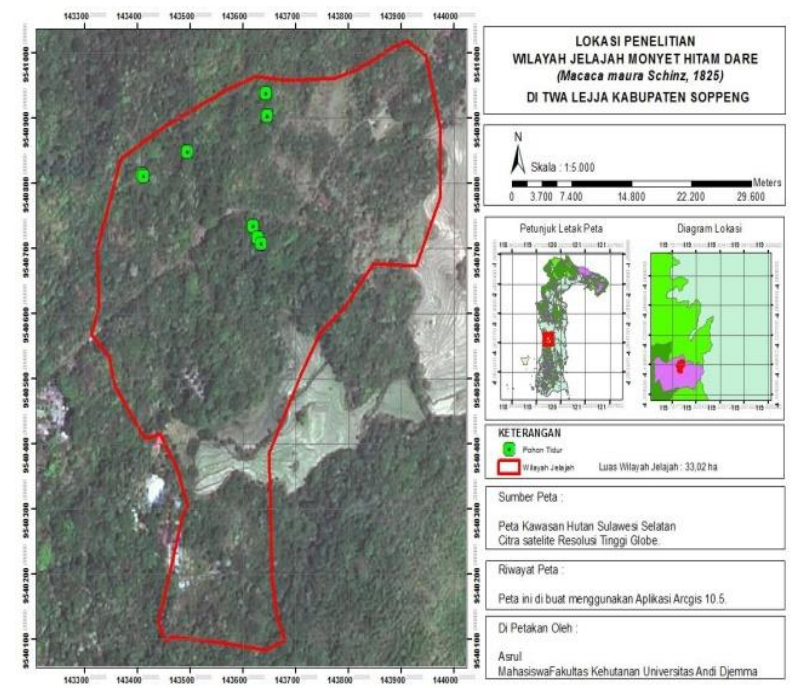

Gambar1: Lokasi Penelitian padaWilayah Jelajah Macaca maura

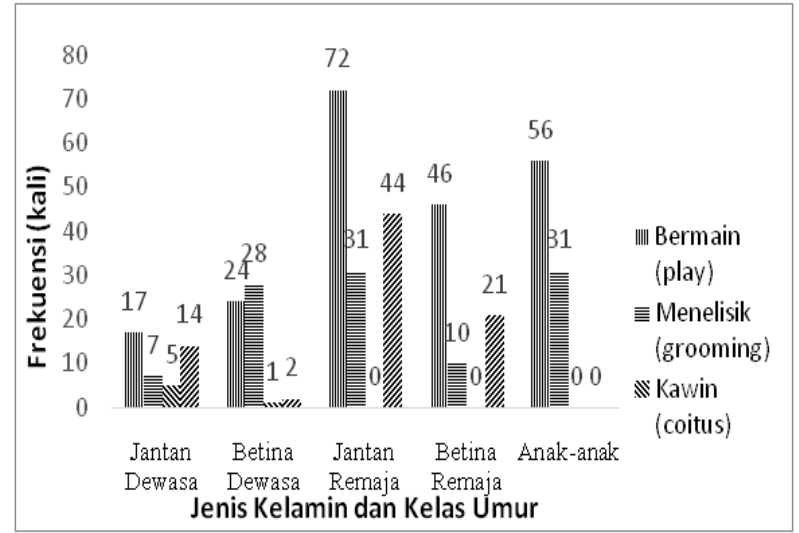

Gambar 2. Frekuensi (kali) Perilaku Interaksi Sosial Macaca maura

Data hasil seluruh frekuensi perilaku sosial Macaca maura menunjukan bahwa perilaku bermain sangat mendominasi semua jenis kelamin dan kelas umur Macaca maura. Frekuensi tinggi dimiliki oleh kelas umur remaja dan anak-anak dengan nilai 72 kali (jantan remaja), 46 kali (betina remaja), dan 56 kali (anak-anak). Hal ini disebabkan pada umur tersebut perilaku bermainMacaca maura sangat aktif dengan bergelantungan pada pohon dan dan bergerak. Pada kelas umur jantan dewasa perilaku bermain juga menunjukkan frekuensi yang tinggi yaitu 17 kali. Sedangkan pada betina dewasa perilaku bermain memiliki frekuensi yang lebih rendah dari perilaku menelisik. Hal ini didukung oleh Atmojo (2008) yang menyatakan bahwa anak Macaca maura menghabiskan banyak waktu untuk bergerak dibanding dengan kelompok usia lain yang bertujuan melatih gerak motoriknya dan mempelajari tentang lingkungan, meningkatkan kemampuan pergerakan, dan komunikasi social. Aktivitas bermain dilakukan dengan cara berkejarkejaran ataupun tarik-menarik.

Perilaku menelisik tertinggi dimiliki oleh kelompok umur jantan remaja dan anakanak dengan nilai frekueni yang sama yaitu 31 kali, sementara betina dewasafrekuensi menelisiknya sebesar 28 kali. Hal ini menunjukan bahwa individu remaja, anak anak dan betina dewasa lebih banyak terlibat 
dalam perilaku selisikpasangan baik sebagai pelaku ataupun penerima selisik. Menurut Nugroho (2015) biasanya betina sering melakukan autogrooming karena betina lebih banyak beraktivitas seperti makan, bergerak, mengasuh bayi, dan koalisi yang lebih tinggi dari jantan sehingga terdapat banyak kotoran di tubuhnya.Perilaku menelisik dilakukan sepanjang hari sejak pagi sampai sore, tetapi peningkatan aktivitas grooming ditemukan pada pagi hari sebelum turun dari pohon tidur. Selain itu, perilaku menelisik juga terjadi pada saat makan, istirahat dan berpindah tempat.

Sedangkan frekuensiperilaku konflik dan kawin tertinggi dimiliki oleh kelompok umur jantan dewasa, dengan frekuensikonflik sebanyak 14 kali dan kawin sebanyak 5 kali. Hal ini disebabkan kelompok umur jantan dewasa merupakan individu yang dominan di dalam sebuah kelompok untuk menguasai sumberdaya yang ada. Jantan dewasa juga sering melakukan konfik untuk memperebutkan makanan, betina dan wilayah teroterial, sehingga dua perilaku tersebut di dominasi oleh jantan dewasa. Menurut Saroyo (2005), konflik sering terjadi pada kelompok jantan dewasa karena kompetisi terhadap pakan terjadi jika kuantitas pakan yang tersedia dalam jumlah terbatas, atau jika sumber pakan yang tersedia sangat disukai monyet, sementara kawin pada jantan dewasa tinggi karena pada usia ini merupakan usia untuk bereproduksi.Proses kawin yang teramati di lapangan yaitu mulai dari individu jantan dewasa mendekati individu betina dewasa dan langsung melakukan proses kawin ataupun diselingi dengan perilaku menelisik.

\section{Waktu Perilaku Sosial Macaca maura}

Berdasarkan durasi waktu perilaku sosial Macaa maura menunjukan bahwa total dan persentase waktu tertinggi yang digunakan oleh semua kelompok umur adalah perilaku bermain, khusus kelompok umur anak-anak menggunakan waktu terlama untuk bermain yaitu 10.602 detik atau $62,01 \%$. Selanjutnya disusul oleh kelompok jantan remaja dan jantan dewasa dengan durasi waktu 8.566 detik $(60,13 \%)$ dan 6.508 detik $(55,88 \%)$. Sementara jenis kelamin betina baik dewasa dan remaja memperlihatkan proposi watu yang digunakan untuk bermain paling rendah, khusunya pada kelompok betina dewasa yaitu 4.841 detik (42\%). Walaupun durasi waktu perdetik yang digunakan oleh betina dewasa dan remaja hampir sama, tetapi persentasi waktu bermain betina remaja lebih besar yaitu 64,83\% (Tabel 2)

Pada perilaku menelisik, kelompok anak-anak dan betina menggunakan waktu . menelisik terbesar dibandingkan dengan kelompok umur yang lain. Kelompok anakanak memperlihatkan durasi waktu menelisik paling lama yaitu6.494 detik (37,98\%). Sedangkan betina dewasa menggunakan waktu untuk menelisik lebih rendah yakni 5.398 detik walaupun presentasi waktunya besar (47,53\%). Perilaku menelisik anak terlihat pada pagi, siang, dan sore hari bahkan pada waktu istirahat dimana kelompok berhenti di suatu lokasi setelah berjalan atau sesudah makan. Anak melakukan perilaku tersebut dengan sesama kelompok usianya maupun dengan induknya. Yanti (2016) menyatakan perilaku yang banyak muncul dalam interaksi sosial terjadi pada kelompok yang masih muda (anak), karena bermain merupakan bentuk interaksi terhadap individu lain dalam populasi yang berfungsi meningkatkan kondisi fisik, mengembangkan kemampuan dan ikatan sosial dan mebantu hewan untuk belajar kemampuan spesifik. Sedangkan menurut Nasution (2011) individu anak cenderung melakukan aktivitas menelisik terbatas pada hubungan kekerabatan antara individu lainnya .

Perilaku kawin hanya ditemukan pada kelas umur dewasa yaitu jantan dan betina. Total frekuensi kawin yang diamati selama penelitiaan sebanyak 6 kali, dimana jantan dewasa kawin sebanyak 5 kali dan betina 
dewasa kawin hanya satu kali. Berdasarkan durasi waktu, lama perilakukawin ditunjukkan oleh dewasa betina yaitu 240 detik atau 4 menit, walaupun frekuensi kawin hanya satu kali. Sedangkan jantan dewasa dengan frekuensi sebanyak 5 kali kawin menghaiskan waktu total sebanyak 300 detik atau 5 menit. Hal ini menujukkan bahwa durasi waktu kawin jantan betina lebih lama dibandingkan jantan dewasa. Perilaku ini banyak dilakukan di daratan atau di permukaan tanah daripada di atas pohon. Jantan dewasa memiliki frekuensi tingkat perilaku kawin yang tinggi karena merupakan pemimpin dari kelompok tersebut atau biasa disebut dengan pejantan dominan, sehingga individu ini berkuasa dalam memperoleh individu betina yang diinginkannya. Hal ini sejalan dengan Gusnia (2010), yang menyatakan bahwa pejantan yang memiliki hierarki tertinggi dalam kelompoknya juga memilki tingkat frekuensi perilaku seksual tinggi dan dapat mengawini beberapa betina tanpa harus berkelahi dengan jantan lainnya.

Perilaku konflik tertinggi juga dimilki oleh kelompok umur jantan dewasa dengan persentase waktu aktivitas sebesar 25,35\% dengan durasi waktu 2.953 detik dalam 15 hari pengamatan. Kemudian disusul oleh jantan remaja dengan persentasi waktu $20 \%$ atau 2.849 detik. Konflik cenderung ditunjukkan oleh Macaca maura pada saat perebutaan makanan, mempertahankan wilayah jelajah dan pada saat kembali ke pohon tidur stetlah seharian berjelajah. Tingkat konflik tertinggi ditemukan pada waktu pagi hari dimana terjadi perebutan makanan antara individu dikelompok tersebut karena ketersediaan pakan yang kurang, namun tidak meningkat lagi pada siang hari. Setelah itu konflik kembali tinggi pada waktu sore hari yang terjadi akibat adanya perbutan tempat tidur dimana individu yang dominan lebih berkuasa untuk memilih tempat dimana saja yang diinginkannya, meskipun di tempat tersebut sudah ada individu yang menempatinya terlebih dahulu. Hal ini sejalan dengan pernyataan Meisvhili (2009) yaitu perilaku konflik ini bertujuan untuk menjaga status hierarki dominansi yang memungkinkan jantan dewasa untuk memilki akses yang lebih dalam kelompoknya.

Tabel 1. Durasi Waktu Perilaku Sosial Macaca maura

\begin{tabular}{|c|r|r|r|r|}
\hline \multirow{2}{*}{$\begin{array}{c}\text { Jenis Kelamin dan } \\
\text { Kelompok Umur }\end{array}$} & \multicolumn{4}{|c|}{ Total Waktu (detik) dan Presentasi Waktu (\%) Perilaku Interaksi Sosial } \\
\cline { 2 - 5 } & Bermain (play) & Menelisik (grooming) & Kawin (coitus) & Konflik (agonistic) \\
\hline Jantan Dewasa & $6508(55,88)$ & $1886(16,19)$ & $300(2,58)$ & $2953(25,35)$ \\
\hline Betina Dewasa & $4841(42,62)$ & $5398(47,53)$ & $240(2,11)$ & $879(7,74)$ \\
\hline Jantan Remaja & $8566(60,13)$ & $2830(19,87)$ & 0 & $2849(20,00)$ \\
\hline Betina Remaja & $4842(64,83)$ & $961(12,87)$ & 0 & $1666(22,31)$ \\
\hline Anak-anak & $10602(62,01)$ & $6494(37,98)$ & 0 & 0 \\
\hline
\end{tabular}

Keterangan: a) Total waktu perilaku bermain pada jantan dewasa yaitu 6508 detik

b) Presentasi waktu perilaku bermain pada jantan dewasa yaitu $55,88 \%$ 


\section{KESIMPULAN}

Berdasarkan hasil penelitian bahwa perilaku sosial Macaca Maura didominasi oleh perilaku bermain pada semua jenis kelamin dan kelas umur dengan frekuensi tinggi dimiliki oleh kelas umur remaja dan anak-anak. Demikian halnya dengan durasi waktu yaitu total dan persentase waktu tertinggi oleh kelompok umur anak-anak menggunakan waktu terlama untuk bermain. Selanjutnya disusul oleh kelompok jantan remaja dan jantan dewasa. Hal yang sama pada perilaku menelisik tertinggi dimiliki oleh kelompok umur jantan remaja dan anak-anak dengan nilai frekuensi yang setara, tetapi kelompok anak-anak menghabiskan waktu terlama dibanding dengan kelompok jantan remaja. Sementara perilaku konflik dominan diperlihatkan oleh kelompok jantan dewasa. Sedangkan perilaku sosial kawin hanya dilakukan oleh kelompok umur dewasa dengan frekuensi serta total waktu yang digunakan paling rendah.

\section{DAFTAR PUSTAKA}

Atmojo, I. R. 2008. Perilaku Anak Orangutan (pongo pygmaeus pygmaeus) di Pusat Primata Schmutzer, Taman Margasatwa Ragunan dan Taman Safari Indonesia. Sekolah PascaSarjana. Institut Pertanian Bogor. Bogor.

CITES (Convention on International Trade in Endangered Species of Wild Fauna and Flora ). 2008. https://www.cites.org/. diakses pada tanggal 27 Mei 2018

Groves, C.P. 1980. Speciacion in Macaca: the View from Sulawesi. In the Macaques: Studies in Ecology, Behaviour and Evolution (D.G. Linburg.ed). Van Nostrang. New York

Gumert. 2000. Payment for sex in macaque mat-ing market. Animal Behaviour, 74: 1655-1667.
Gusnia NA. 2010. Perilaku Seksual monyet ekor panjang(macaca fascicularis Rafless 1821) Di penangkaran semi alami pulau tinjil, Kabupaten pandeglan, Provinsi Banten.

IUCN (International Union for Conservation of Nature. 2018. https://www.iucn.org/. diakses pada tanggal 27 Mei 2018

Kliner, T. 2001. The Sulawesi Macaques: a Literature Review. Department of Biological Sciences, Manchester Metropolitan University, Manchester.

Labahi, P.A. 2015. Macaca maura Satwa endemik Sulawesi Hidup Damai Di Hutan Diklat Tabo- tabo

Lee, G.H. 2012. "comparing the relative benefitsof grooming contact and fullcontact fairing for laboratory housed adult female macaca fascicularis" Aplied animal behavior science. 137:157-165.

Martin P. dan Bateson P. 1993. Measuring Behaviour: An Introduction Guide $2^{\text {nd }}$ Ed. Cambridge University Press. New York.

Meisvhili, N.V. Chalyan, V.G.M. Roskova, Ya Yu. 2009. "The Cause of Intragroup Aggresion in rhesus Macaques". Neursciense and behavioural Phsyology. \#9(2): 147-151

Mondoringin, G.H. Wungow, Rita S.H. Joice J.I. Rompas. 2016. Identifikasi Tingkah Alpha Male Monyet \Hitam (Macaca Nigra) Di Cagar Alam Tangkoko. Fakultas Peternakan Universitas Sam Ratulangi Manado.Vol. 36 No. 1 : 95 104

Murti, D.B. 2007. Adaptasi Orangutan : Studi Primatologi Mengenai Adaptasi Orangutan Menyangkut Masalah Perilaku Lokomosi dan Perilaku Sosial di Kebun Binatang Surabaya. [skripsi]. Surabaya. Airlangga University.

Nasution, E. k. Swandyasturi, S.N.O. Wiryanto. 2011. Aktivitas Harian dan Populasi Monyer Ekor Panjang 
(macaca fascicularis Raffles) di

Kawasan Wisata Cikakak Wangon.

Prosiding seminar Nasional Hari

Lingkungan Hidup. Konservasi

Sumberdaya Alam dan Lingkungan.

Nugroho A, Sugiyarto. 2015. Kajian perilaku

kera ekor panajang (macaca

fascicularis) dan lutung (trachyoitheus aurutus) di coban Rondo, Kabupaten

Malang,.Pendidikan biologi dan

Fakultas keguruan dan ilmu pendidkan , Universitas Bangun Nusantara

Saroyo, 2005. Karakteristik Dominansi Monyet Hitam Sulawesi (Macaca Nigra) Di Cagar Alam Tangkoko- Batuangus, Sulawesi Utara. Institut Pertanian Bogor. Bogor

Supriatna, J. And E.H. Wahyono. 2000. Panduan Lapangan Primata Indonesia. Yayasan obor Indonesia. Jakarta.

Tasin, 2007. Tingkah laku agonistic Monyet Hitam Kelompok Rambo I di Cagar Alam Tangkoko Batuangus. Skripsi. Fakultas Peternakan Unsrat. Manado

Watanabe K., and E. Brotoisworo. 1982. Field obeservation of Sulawesi Macaques. Kyoto Univ. Overseas Res. Rep. Asian non Human Primate 2: 3-9.

Whitten, A.J., Mustafa M., and Handerson GS. 1987. Ecology Sulawesi. Gadjah Mada University Press. Yogyakarta.

Yanti N. Adriansyah A. Agatha A. Rusiwardani N.S. Santoso M. Yulianti H. 2016. Laporan Kuliah Lapangan Biologi Perilaku (BI-3201) Aktivitas Harian Monyet Ekor Panjang (macaca fascicularis) di TWA/CA Pangandaran. 